\title{
VISIONARY LEADERSHIP ROLE: BUILDING A GHOST TOWN CIVILIZATION
}

\author{
Makna Ani Marlia \\ Doctoral Program of Management, Faculty of Economics, \\ Andalas University, Padang, Indonesia \\ Rahmi Fahmy \\ Faculty of Economics, Andalas University, Padang, Indonesia \\ Hendra Lukito \\ Faculty of Economics, Andalas University, Padang, Indonesia \\ Ratni Prima Lita \\ Faculty of Economics, Andalas University, Padang, Indonesia \\ Rida Rahim \\ Faculty of Economics, Andalas University, Padang, Indonesia
}

\begin{abstract}
This paper aims to explore the role of a visionary leader in rebuilding the city's civilization dubbed the ghost town as a result of being abandoned by its inhabitants because of the cessation of mining activity in Sawahlunto City. This mayor-level visionary leader's role is considered successful as an example of a successful visionary leader for achievement in reviving the dying city and making the city a growing economy. The methodology used in this study is a literature review and a comprehensive library review and case study approach. The collecting data were conducted by interviewing some local communities and women entrepreneurs in Sawahlunto to strengthen this study. The interview was recorded in video recording. The success of the visionary leader begins with the success of the leader on the city's vision. The regulatory legitimacy becomes a reference and common goal in building the city. The success is associated with the vision implementation sustainability through real action by the next leadership's successor encompasses the key success factor. The success is indicated by the achievement gained in 2019 as one of the world Heritage Sites by UNESCO. However, some questions are proposed related to the city's vision sustainability on age and destination, the forming of cadres of leadership, and the next leader's vision commitment.
\end{abstract}

Keywords: Leader, Vision, Visionary Leadership, Mining Tourism City. 
Cite this Article: Makna Ani Marlia, Rahmi Fahmy, Hendra Lukito, Ratni Prima Lita, Rida Rahim, Visionary Leadership Role: Building a Ghost Town Civilization, International Journal of Management (IJM), 11 (1), 2020, pp. 31-55. http://iaeme.com/Home/issue/IJM?Volume=11\&Issue=1

\section{INTRODUCTION}

In a competitive and rapidly changing business environment, effective leadership becomes one of the most critical needs and becomes a must ( (Bass, 1985); (Bryman, 1986); (Pierce \& Newstrom, 1995)). Environmental changes that occur so rapidly, requiring leadership that has a lot of innovation, creativity, and individual thoughts and initiatives (As-Sadeq \& Khoury, 2006). Leadership can be understood as an effort to move all resources and tools available in an organization consisting of human resources and non-human resources. (Dimiyati, 2014).

In organizations, companies or institutions consisting of various resources, the leader becomes a crucial element because the success of an organization in achieving its objectives is highly dependent on its leadership ability to build climate Cooperation to manage and mobilize all existing resources optimally (Dimiyati, 2014). Leadership roles will never be separated from the implementation of management functions in the organization namely planning, budgeting, organization, staff,, actuating, coordinating, controlling, and evaluation (Dimiyati, 2014). Demands in the face of the dynamic changes that occur leadership qualities are needed, not only on the implementation of daily functions such as giving orders, advising, and delegating authority to their subordinates, but how Communicate the vision, mission, and objectives of the Organization in a clear and comprehensive manner to all the users associated with the organization. In line with that, Kotter (1990) says that it is necessary for a future leader who has a vision, values, assumptions and a promising paradigm, by empowering the workforce with a team that is oriented towards successful organizational success. Without the vision and values that support the organizational structure to the future, leaders may not be able to make decisions in line with the objectives of the organization (Bryman, 1986); (Kotter, 1990).

Every aspect of the change will affect the development of organizations, institutions, and countries. Therefore, it takes leadership that can think far forward, able to overcome all changes, and the development of the era in the very the demands of diverse needs become highly relevant. Organizations need leaders who can develop their organization well and far ahead, beyond their age (Dimiyati, 2014). Visionary leadership is the absolute requirement for organizations that want to grow decades ahead, so the vision becomes very important. Why is vision becoming all about a leader? Because of the vision that leads the leader. The vision will color the target and become fuel to move the progress. Vision also serves as a trigger of passion for others to follow leaders. A leader who is without a vision will not accomplish anything; she/he spins the swivel in a circle (Maxwell, 2019).

This paper aims to explore the role of a visionary leader in an organization in that it presents major-level district officials who are assessed as successful as examples of successful visionary leaders on their achievements Returned to the almost dead city of Sawahlunto since mining activities were discontinued and made the city with economic growth continuing to wiggle. The leaders of the city of Sawahlunto can be assessed as the agent of change from the city change Subari Sukardi the year 2001 S. D 2003 he managed to invoke change by changing the idea of changing the city's vision as the beginning of the city change Sawahlunto. Amran Nur Mayor elected the period 2003 S. D 2013 is the main character who executed and implemented a significant change to the city of Sawahlunto become a cultured mining city, then the next period and Ali Yusuf period 2013 S. D 2018 As an elected leader who emphasizes more on the city's maintenance and sustainability measures with the 
strengthening of the city's identity through various external promotions and maintaining internal value, so that tourism as an industry Global does not damage the value and norms used as a local community identity. "Sawahlunto 2020 becomes a cultured mining city" This moment should be utilized if the next elected leader is a visionary. After arriving at the stage of success, what action did the next elected leader have for the city's sustainability? What revolution will be done?

Sawahlunto is currently still in the leadership of Deri Asta period 2018-2023, which should undoubtedly during his tenure is momentum in making a significant change to the upcoming 15 years as what has been done by the previous visionary leader. Visionary leadership is believed to be able to adapt to the organizations it led to the ever-changing external environment. For the leaders and all the subordinates to be involved in realizing the objectives of the organization, social interaction will be needed to each other and in need to create a conducive and calming work environment. In the process of socializing and interacting, a leader must be able to provide encouragement or enthusiasm to the subordinates in order to achieve the optimal performance of the organization. Many empirical studies have been conducted to assess visionary leadership. Suprayitno (2007) revealed that the organization needs an inspirational and visionary leader of the change to have a vision where the organization would be carried. (Suprayitno, 2007). Lulu Zhou et al. (2018) expressed visionary leadership positively related to the creativity of employees in the organization (Zhou, Zhao, Tian, Zhang, \& Chen, 2018). Kevin S. Groves (2006) expressed that the leader's emotional expressiveness could moderate the relationship between visionary leadership and organizational change, and between visionary leaders and high emotional expressiveness skills that would facilitate major changes in the organization (Groves, 2006). Mclarney C, Rhyno S (1999) used a leadership model ever proposed by Westley and Mintzberg in 1989 about visionary leadership elements and group memberships (Mclarney \& Rhyno, 1999). Taylor C et.al (2014) found a significant relationship between visionary leadership and organizational effectiveness perception (Taylor, Cornelius, \& Colvin, 2014). Tony Manning and Bob Robertson (2002) revealed that it takes leadership more than just visionary leadership to face various situations in the face of change (Manning \& Robertson, 2002). Granit AlmogBareket (2012) found that strong visionary leadership in between is necessary to produce a unique identity and reputation of the organization (Almog-Bareket, 2012). Sonny N and Bill Richardson (1996) found that the main visionary transformer as the type of leadership needed to achieve success through strategic change (Nwankwo \& Richardson, 1996). Stam D, Van Knippenberg D, Wisse B (2010) revealed that the leader's vision motivates the followers by focusing on achieving the desired final condition (Stam, van Knippenberg, \& Wisse, 2010). Raya Yoeli and Izhak Berkovich (2010) revealed that the visionary education leader unites their vision with their organizational vision and personal ethos, it is a key element in formulating the personal vision and organization of leaders (Yoeli \& Berkovich, 2010). Ken Kalala Ndalamba et al. (2018), in his laboratory, invited leaders in contemporary complex organizations to improve their leadership vision by respecting the officials, where leadership capacity strengthens capacity leaders to defend their organization and the people who work in it (Ndalamba, Caldwell, \& Anderson, 2018). Kevin S. Groves (2006) found that there was a connection between the leader's emotional expressiveness and visionary leadership, while the expressive emotional leadership moderates the relationship between visionary leadership and organization change magnitude. Besides, visionary leaders with high emotions with expressiveness skills facilitate significant changes in the organization (Ndalamba, Caldwell, \& Anderson, 2018).

Unlike previous studies on visionary leadership, this paper focuses on how the role of a visionary mayor's district leader performs a variety of changes successfully, especially in changing and implementing vision in the form of tangible activities. It is subject to create the 
welfare and progress of the people in the city of Sawahlunto Sijunjung which is one of the provinces in West Sumatera, in this case, as an example of involving the changing figures of Sawahlunto. The selection of this character is a reason that is quite precise because during the leadership, they experienced a very revolutionary change in the re-branding and re-imagining the city of Sawahlunto. This paper applies a case study approach with data collection techniques based on an interview, audio-video recording, and other related documents. In this case study, the authors describe how the success of the visionary leader in conducting a city vision change as an effort to overcome the death threat of mining cities and how to manage resources in realizing the city change of Sawahlunto as a cultured mining town.

\section{LEADERSHIP}

The theory of leadership in research interests can be concluded from the writings of the early civilizations. Confucius (500 BCE) wrote one of the earliest comprehensive agreements on leadership, and leadership discussions could be found in the writings of Plato, Plutarch, and Caesar. Leadership continues to be an exciting topic, many theories of leadership. Like the theory of leadership discovered by Bass where more than 7,500 studies on leadership were conducted dilakukan (O'Connor \& Jennings, 1960); (R. Stogdill, 1974); (Hollander, 1979); (Nanus, 1992b). The following, the theories of leadership are reviewed from a historical perspective focusing on how the theories of leadership have evolved. To achieve this goal, three approaches can be identified: a trait approach, which dominates leadership studies up to the 1940 's; Behavioral approaches, which were popular until the end of the 1960 's; And the contingency approach, which is currently the dominant approach in the study of leadership (Robbins, 2003); (Robbins, 1996).

\subsection{Trait Theory}

The theory of nature of leadership focuses and develops around a central idea that attempts to learn and isolate the personal qualities and characteristics that distinguish the leaders from non-leaders. They are based on the underlying assumption that leadership is innate, which means that someone is either born as a leader or as a follower. Traits such as intelligence, knowledge, domination, initiation, achievement, responsibility, participation, self-confidence, energy, emotional maturity, stress tolerance, pragmatism, outcome-orientation, ambition, honesty, and integrity are learned and Considered effective leader characteristics (R. Stogdill, 1974); (Robbins, 2003); (Bryman, 1996); (Bass, 1990).

In his paper, Stogdill (1948) contained a review of 124 studies that were targeted at the theory of nature. Although Stogdill concluded that the study of theoretical traits was weak and unconvincing, he stated that leaders exceeded others in some traits, such as intelligence, dependence, social participation, and social and economic status. While this determination was deemed provoking, and then applies to other leadership studies, Stogdill concluded that leadership could not only be defined by the axiom of trait theory. Stogdill postulated that effective leadership depends on the situation as well as the personal characteristics of the leader. He concluded that "one does not become a leader based on possession of some combination of traits" (R. M. Stogdill, 1948). Something in common with Stephen Robbin (1996) Some traits are likely to increase success as a leader, but none of these traits guarantees success. One who has high self-monitoring properties in other words, supple in adapting their behavior in different situations, has a higher chance of becoming a leader in groups than on which Low monitoring self-esteem. The fundamental feature theory has been taken from birth (Robbins, 1996). 


\subsection{Behavioral Theory}

Unlike the theory of nature, the theory of behavior argues that leadership can be taught, and leaders can be made not only natural birth. In this approach, leadership is explored to create leadership. This theory of approach not only focuses on increasing the individual traits of the leader while being directed to the nature of managerial work and the classification of various functions, practices, roles, and behaviors of leaders. It is based on the fact that it contrasts with personality, behaviors can be learned and altered through exercises that in turn, lead to the interest of the trained leaders, and some studies have been conducted to investigate whether it is about behavior to know the most efficient behavior than others (R. Stogdill, 1974); (Bryman, 1986); (Bass, 1990).

The theory of nature affects behavioral theories; behavioral approaches should see what leaders do. A common question underlying this approach: what are the leaders being doing that distinguish them from non-leaders? (Greenberg \& Baron, 2000); (Greenberg, 2003) (Robbins, 2003). According to Robbins (2003), the main difference between nature and the behavioral approach in terms of the application lies in the underlying assumptions. If the theories of character are valid, then the leader of the born is not made. On the other hand, if there are specific behaviors inherent to the leaders, then this behavior can be isolated, discovered, and taught. The main difference between nature and the behavioral approach in terms of the application lies in the underlying assumptions; behavioral approaches do not recognize the change in the situation (As-Sadeq \& Khoury, 2006) (Robbins, 1996).

\subsection{Contingency Approach}

Contingency approaches, often also referred to as situational approaches, this approach emerged in the early 1960s because of the inability of the capabilities of the other approach to describe various aspects of the leader's behavior (Kast \& Rosenzweig, 1973); (Pierce \& Newstrom, 1995). The contingency approach states that effective leaders should adapt their style in a way that is consistent with the important aspects of the organizational context, such as the nature of the task, and the attributes of the employee carrying out the work (R. Stogdill, 1974); (Bass, 1990); (As-Sadeq \& Khoury, 2006). The approach arises as an answer to the question of the best way to lead and dealt with the interaction between the attributes of the leader, the behavior of the leader, and the situation in which the leader exists. The underlying assumption of this approach is that the effect of one variable on leadership relies on other variables. This concept is an excellent insight into the theory of leadership, as it opens the door to the possibility that leadership can differ in any situation (Pierce \& Newstrom, 1995); (As-Sadeq \& Khoury, 2006).

Yukl (1989) reveals that research into situational leadership can be broadly implemented for two different categories; Situational factors and how they influence the behavior of leaders and the behavior of specific, effective, and efficient leaders in different situations. The question is whether the behavior or situation is determined as the dependent variable. Some models to prove that situational variables have proved more successful than others, and as a result, have gained full recognition. The leadership model is influenced by these situational factors consisting of five approaches: the first Model of the contingency leadership theory Model Fiedler, Fiedler develops what the contingency model of effective leadership is, which Say that there is a relationship between leadership styles and favorable situations. Three dimensions of effective leadership according to him: (1) The relationship of leaders and members, (2) the level of the task structure, (3) leader position Authority pemimpin (Luthans, 2006a). Secondly, the situational theory of Hersey and Blanchard, emphasis on situational leadership theory is a theory that focuses on the readiness of its followers. Leaders must assess correctly or initially to know the level of maturity of the followers. Thirdly, leader and 
exchange member theory (LMX) was developed by Goerge Graen, leaders creating groups in and outside groups and subordinates with the status of the group in the will have a higher performance assessment, the level of discharge Employees, and greater satisfaction with their superiors. Fourth, the line and destination model by Robert J. House seeks to predict the effectiveness of leadership in various situations. This theory focuses on how leaders influence the perception of their followers on work objectives, self-development goals, and avenues for achieving future satisfaction objectives. Fifth, the model's participation of leaders by Vroom and Yetto, opposite Fiedler, Vroom, and Yetto assumes that the leader should be more supple to change the leadership style to fit the situation. Using 5 leadership styles that are picturing the continuum of an authoritarian approach to consultative approaches to a fully participatory approach (Bass, 1990); (Bryman, 1986); (Robbins, 2003);(Robbins, 1996), (Greenberg, 2003).

Stephen P. Robbin (2003) mentions the latest approach to leadership, the first theory of attribution of leadership that suggests that the leadership of the mere attribution that people make about other individuals, the attribution theory of Leadership is the perception that effective leaders are generally considered to be committed and consistent, have personality intelligence, friendly, for example, Ronal Reagen leadership during his first leadership perceived as a Have a significant, steadfast, and consistent commitment to the decisions he makes. Both of the charismatic leadership theories, in which the follower makes the attribution of the leaders of the heroic or extraordinary being assessed when they observe certain behaviors, the charismatic leaders give a great influence Followers, if followers feel that the beliefs of the leader are right then they will receive the leadership gladly, they feel saying to the leader, emotionally involved in the mission of the group or organization, and have High-performance objectives. Thirdly, transactional and transformational theories, transactional leaders are leaders who guide or motivate their followers in goals that are enforced by reacting roles and task demands with characteristics such as rewarding Depending on the efforts and achievements, perform well and recognize achievements, management except for active-guarding and seeking deviations from the rules or standards and immediately take corrective and passive actions-only interfere if the standard Unfulfilled, Leissez-Faire: waive responsibilities and avoid decisions, while transformational leaders provide individualized consideration and intellectual reasoning, and have charisma with characteristic of giving Vision and mission, instill pride, gain respect and trust, inspired by communicating high expectations, using lambing-lambing to focus efforts, simply expressing necessary intent, giving Intellectual property by encouraging the intelligence, rationality, and problem solving researched and individualized considerations by giving personal attention, treating employees individually, training, advice. Fourth, the visionary leadership theory is the ability to implement an attractive, trustworthy, and realistic vision of the future of the organization or for a growing and improved organizational unit (Robbins, 1996); (Robbins, 2003); (Dimiyati, 2014).

Leadership in an organization is one of the critical factors that support organizational success in achieving goals. In a community environment, consisting of a formal organization or an informal organization, there is always someone who is considered more than the other. A person who has these abilities is then appointed or appointed to govern others. Usually, such a person is called a leader or manager (Zainal, Hadad, \& Ramly, 2017). The issue of leadership is as old as human history because leadership needs humans. Do people in society or organization not be able to perform their duties and functions without a leader? Some of the reasons were also discovered to answer the question: first, because many people who need a leader figure, secondly, in some situations the leader needs to appear representing the group, third, as a place to takeover risk when There was a pressure on the group, and the fourth as a 
place to put power. John Whitley said an effective leader could revive an organization, and leaders can cause a difference (Robbins, 1996).

The leadership of the language is leadership that comes from the world leader, said leader appeared in the 1300s, and the word leadership emerged later in the year 1700s (Zainal et al., 2017). Many works of literature on leadership, there are even some that confuse and contradict each other, so to explain what makes the leadership compelling needs to be learned from several approaches, as explained Previous (Zainal et al., 2017).

The science of leadership is growing in line with the dynamics of human life development. Stephen P. Robbins in (Fahmi, 2018) said leadership was the ability to influence a group toward achieving the objectives. The same understanding was also discovered by Richard L. Daft, who said leadership is the ability to influence others who are directing them toward achieving the objectives (Fahmi, 2018). Two of the opinions were reinforced by G. R Terry, who gave the defendant: that leadership is an activity that affects others to struggle hard for a common purpose. Another opinion comes from Ricky W. Griffin (Fahmi, 2018), who says leaders are individuals who can influence the behaviour of others, without relying on violence, leaders are individuals who are accepted by others as leaders.

Kartini Kartono in 1983 (Fahmi, 2018) explained that three theories led to the emergence of leaders. First, the Genetic theory (trait theory) says that the leader has already had talent since he was born and cannot be made. This theory emphasizes that leaders are destined to become leaders. Where this theory adheres to a deterministic view or in other words, a view that has been determined in the past, secondly, social theory (can be categorized similarly to behavioural and situational leadership theories) says that a leader was not born, but a prospective leader could be prepared by students and formed so that he would be the leader A great day, with the meaning of the word theory, it is the genetic theory that everyone has the opportunity to become a leader through the education and encouragement of various parties. Thirdly, the ecological theory or synthesis that says a person will succeed in becoming a leader when he does indeed have the talents of the leader. Then this talent was developed through education, encouragement, and experience that would form personal as a person leader.

So, leadership is not a position or a person but a process of influence, which is often aimed at mobilizing people towards change, such as changes in values, attitudes of approach, behaviour, and Ideology (Tomsic \& Sinclair, 2014). Fiedler defines the leader as a person who is given the task to direct and coordinate group activities that are relevant to the task; she/he is also the one who bears the primary responsibility for carrying out these functions in a group (Simpson \& Fiedler, 1969). The effectiveness of a group, measured in terms of performance in completing the assignment of critical tasks, depends on the interaction between the leader style concerning the members of the group (the underlying structure and consistent needs Motivate its behaviour in various leadership situations) and the extent to which the situation allows the leader to influence the group members (Simpson \& Fiedler, 1969). In connection with the leadership of Barry Posner who is a leadership teacher doing further observations on the leadership, which says that the past believes that the leader is like a ship captain, authoritative and calm, and realizes that a leader is also a man, who needs touch, empathy, and is in his subordinates, the leader must be a part of what is happening and not apart from what is happening (Luthans, 2006b). Daniel Goleman argues that a leader must have the criteria and properties of nature such as intelligence, toughness, determination, and vision, which demonstrates the importance of personal qualities a leader called Emotional intelligence (emotional Intelligence) that concerns self-awareness, self-regulatory, motivation, empathy, and skill (Goleman, 2011). Kartini Kartono (1994) stated that a leader is a person who has the advantage and proficiency proficiency in the field so that he can influence others 
to jointly perform certain activities to Achievement of one goal or multiple objectives (Dimiyati, 2014).

From the theory of the origin of the leadership referred to in this study refers to the ecological theory or synthesis by Kartini Kartono (1983) stating that the leader has not only talent since he was born but also with the formation with Education and exercises and opportunities given to him (Fahmi, 2018). In the case study of these two regional leaders were elected people each twice the period to lead the city Sawahlunto Sijunjung, unlike the previous and subsequent leaders who were only one time period, this indicates A strong belief in the society of these two leaders to lead the city on a joint vision change to build the future to realize the welfare and progress of the city that has almost died from mining activities. Stopped being critical to 21 st-century leaders where they will face increased complexity, uncertainty, and challenging problems, the selection, and development of visionary leaders must be carried out very carefully and A definite transition plan. In short, because "There is no more powerful engine that moves the organization to excellence and long-term success in addition to the vision of the future is interesting, valuable, and can be broadly divided " (Nanus, 1992b).

\section{VISIONARY LEADERSHIP}

Most of the research conducted on leadership argues that the exemplary leader portrayed by his followers is a description of the visionary leader and inspirational (Rafferty \& Griffin, 2004); (Conger, 1999); (Groves, 2006). While empirical studies and recent meta-analytic reviews demonstrated a strong effect of visionary leadership at the analysis level of individuals, groups, and organizations (Groves, 2006). Shared vision can be achieved if everyone has the same picture and commitment to be able to say it because with a vision is a power or power to make changes in the organization, the vision will encourage the organization always to grow, learn and thrive in maintaining its survive so that it can endure to future generations (Dimiyati, 2014).

Research by Aribowo Prijasaksono and Roy Sambel (1973) In his laboratory said effective leadership begins with a clear vision, the vision will also strength in the process of change, which encourages the occurrence of the process A blast of creativity through the integration or synergy of various skills of the people in the organization, where the vision of two aspects are visionary role and implementation role (Dimiyati, 2014). Leaders not only build vision for the organization, it must also have the ability to communicate and describe the vision into a series of actions or activities that are an effort to achieve the vision, it is also a responsive leader and always responsive to each problems, needs, hopes, and dreams of the people he led, always active and proactive in finding solutions from every problem or the challenges faced by the Organization (Dimiyati, 2014).

Corinne McLaughin (1987) introduced a visionary leader as a man who was able to build a new dawn (a) that worked with intuition, imagination, passion, and boldness, he presented challenges as an effort to give his best to Organization, and it is an evocative thing to achieve organizational objectives. The visionary leader has a distant view as a social innovator, a change agent and a big picture, always thinking strategic (Dimiyati, 2014).

Visionary leadership is a dynamic and interactive phenomenon, as opposed to the direct process and assumes. The study of strategic vision should consider strategic content as well as strategic context of products, markets, problems, processes, and organizations, and assumes various visionary styles (Westley \& Mintzberg, 1989a); (Mclarney \& Rhyno, 1999), it is based on the three assumptions made by Westley and Mintzberg which later became the basis of analysis for the work of Mary Parker Follett. The first assumption discusses the dynamic nature of visionary leadership, which speaks of visionary leadership, Westley and Mintzberg 
suggest using drama metaphors to illustrate the visionary leadership process. Their ideas are embodied in the model shown in Figure 1. In drama, action, and communication coincide, actors and spectators, ideas, and actions are all unified in the ongoing dramas. They are all start with ition. The actor develops an excellent working knowledge of the subject. Strategic visionaries mean that: strategic perception (developed) through practice and feeling level for business, products, market, and technology, such as through cognition awareness (Westley \& Mintzberg, 1989a). The visionary leader invites their followers to see and feel the vision of the leader. Through their words and actions, the visionary leaders communicate their vision; this includes a variety of dramaturgy devices such as time, movement, views, movements, and props. Visionary leaders create a vision that forms a bridge between leaders and followers and between ideas and actions. The final stage in this process is a relief, which can be described as audience participation. The visionaries turn strategies into visions through interactions with their followers. Here leaders and followers create a shared vision (Mclarney \& Rhyno, 1999).

Leaders have realized that "vision" is a guiding light and driving force for the organization to have a real vision (Nanus, 1992b). Vision is a good starting step to determine whether an existing or proposed vision is the right vision for the organization ("Visionary leadership: Creating a compelling sense of direction for your organization," 1993). Benis and Nanus (1997) Define that visionary leadership is a picture of the future we want together (Adriansyah, 2015). Visionary leadership is the ability of the leader to create, formulate, communicate, socialize, transfer, and implement concepts, thoughts, and ideas that come from him or from the results of social interactions In the organization and stakeholders that serve as the ideals of the Organization in the future that want to be achieved or realized through a joint commitment (Adriansyah, 2015).

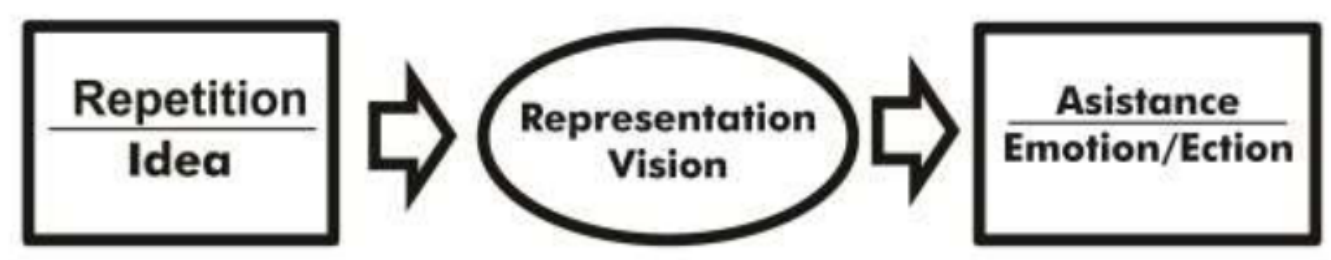

Figure 1. Use drama to illustrate visionary leadership (Mclarney \& Rhyno, 1999)

Burt Nanus (1992) says that organizational vision should produce an alternate vision. Nanus recommends formulating at least three possible scenarios for an organization. He provides models to assess the most critical developments of an organization. Determining the priorities for the future and choosing a subset of each priority is part of the organizational analysis. The leader must be a synthesizer; For example, they need to find similarities between situations despite differences that can separate them, and synthesize new concepts by taking old concepts and combining them in new ways. The visionary leader is responsible for establishing the organizational direction, committing to it, empowering employees to act, listen to and supervise feedback, and put the organization in a position to achieve its most enormous potential (Nanus, 1992a).

Seth Kahan (2002) revealed that visionary leadership involves the ability, capacity, and extraordinary expertise to offer future success. A visionary leader can anticipate any incident that may arise, manage the future, and encourage others to do the right ways. This means that visionary leaders could see challenges and opportunities in the organization to reach the goals (Adriansyah, 2015).

Burt Nanus (1992) further mentions that visionary leadership requires four crucial competencies. The competency in question is the first, able to communicate effectively with 
various leaders and other employees in the organization to produce "guidance, encouragement, and motivation", second, understand the external environment and able to React precisely to all threats and opportunities, the three leaders take an essential role in shaping and influencing the practice of organizations, procedures, products and services, leaders engage in organizations to maintain and maximize service Towards the future of the Organization, the fourth, visionary leader can develop ' imaginative imagery ' to anticipate the future, such as data ability to access the future needs of consumers, technology, he must also have the ability to regulate the organizational resources in order to equip themselves against the emergence of these needs and changes (Dimiyati, 2014).

Furthermore Barbara Brown (1998) said the visionary leader should have ten competencies to have, namely: (1) visualizing, the visionary leader should have a clear picture of what to accomplish and have a target that Obviously when it will be achieved, (2) futuristic thinking, the visionary leader thinks where the business position is at the moment and thinks the desired position in the future dating, (3) showing foresight, the visionary leader is a planner that can Estimate the future by considering what it wants to do and consider the technologies, procedures, organizations and other factors that affect the plan, (4) proactive planning, setting goals and strategies that are specific to achieving Such targets, visionary leaders can anticipate or consider potential obstacles and develop alternative plans to overcome obstacles, (5) Creative thinking, face the challenges of visionary leaders trying to find alternatives A new exit concerning issues, opportunities and problems, (6) Taking risks, dare to take risks and consider failures as an opportunity not a failure, (7) Process alignment. Aligning the process by knowing how to connect its own goals to the organization's goals, and aligning the tasks and work of each department across the organization, (8) The coalition building, building in order to achieve the self-target, he must create a harmonious relationship both inside and outside the organization and actively seeking opportunities to cooperate with a wide range of individuals, departments and specific classes, (9) Continuous learning, can Regularly be taking part in training and other types of development, both inside and outside the organization, it can test any interaction, negative or positive, to study the situation and be able to pursue opportunities to cooperate and take part in projects that can expand knowledge, giving challenges of thinking and developing imagination. (10) Embracing change. Visionary leaders know that change is an essential part of growth and development when faced with unwanted or unanticipated changes, the visionary leader by actively investigating a path that can provide benefits to those changes (Adriansyah, 2015).

The four roles that the visionary leader must perform in carrying out his leadership according to Burt Nanus (1992), first, the direction setter role. Leaders present a vision, convince the idea of the achievement or target of the organization in the future, and involve people from "get-go" which is the essence of leadership, as determining the direction of the leader delivering vision, communicating it, Motivate workers and associates, and convince people that what is done is true, and support participation at all levels and on business towards the future. Secondly, the agent of change which is an important role, the external environment in the context of change is the center of Change, economic, social, technological, and political changes that occur continuously, sometimes ongoing Dramatically and sometimes slowly, effective leaders must continuously adapt to these changes and forward-thinking about potential changes and what can be changed, leaders should be able to anticipate Situations or events that could threaten the future success of the organization are certainly taking into consideration the flexibility and risk of changing environmental consequences. Third, the spokesman (spokesperson). Getting the "message" out, and speaking, can be said to be an important part of dreaming of the future of an organization. An effective leader is also someone who knows and respects all forms of communication available, in order to explain and build support for future visions. The leader, as a spokesperson for the vision, must 
communicate a message that ties everyone into engaging and touching the organization's vision - internally and externally. The vision that is conveyed must be beneficial, exciting, and create excitement about the future of the organization. Fourth, effective leader coaches should be good coaches; this means that a leader must use group cooperation to achieve the stated vision, optimizing the ability of the entire "player" to cooperate, Coordinate their activities or business, toward "achievement of victories," or to the achievement of an organizational vision. Leaders, as coaches, guard workers to concentrate on the realization of the vision by giving hope, direction and build trust among the players that are instrumental to the organization and its vision for the future (Nanus, 1992b);(Adriansyah, 2015);(Nanus, 1992a).

The inherent characteristics of the visionary leader depict all attitudes and behaviors oriented towards the achievement of the vision, the foresight and are accustomed to facing all risks and challenges (Adriansyah, 2015), some traits that characterize the Leader Visionary (a) insightful into the future, acting as a motivator, oriented to the best performance for empowerment, the ability to provide systematic concrete direction, (b) Dare to act in achieving goals, full of trust and are always ready to face risks, which at the same time, the visionary leader also demonstrates careful, thorough and accurate calculations, looking at resources, particularly human resources as valuable assets and providing Good care and protection against them, (c) Being able to rally others for hard work and cooperation in reaching out for purpose, model (exemplary) that consistently demonstrates its leadership values, provides feedback Positive, always appreciating the hard work and achievement demonstrated by anyone that has contributed to the Organization, (d) able to formulate clear vision, inspirational and evocative, manage ' dream ' come true, invite others To change, be able to inspire, motivate others to work more creatively and work harder to get better situation and conditions, (e) able to transform vision into action, communicate well the intent of vision to people Others, and are personally very committed to such visions, (f) holding fast to his own established spiritual value, having strong personality integrity, radiating energy, vitality and willpower to always stand on Positions that are in line with spiritual values, (g) To build relationships effectively, reward and respect, care deeply about others (subordinates), look to others as valuable assets to be paid attention to, Treat them well and ' warm ' like this leader family is very responsive to all the needs of others and help them grow, self-reliant and guide find their future path, (h) innovative and proactive in Discovering the ' New World ', helping to transform the conventional way of thinking (old mental maps) into a dynamic new paradigm with a breakthrough of creative and productive thinking. (Outbox thinking)'. Being eager in swinging the steps of change, rather than just reactive to the events. Strive to be able to use a ' win-win ' approach rather than ' win-lose ' (Adriansyah, 2015).

Leaders are the ones who have the agility, speed, and adaptability to lead the organization. A leader plays a vital role in facing various organizational conditions that are continually changing. Organizational flexibility is mainly the work of people who can act proactive, creative, innovative, and non-conventional. A leader is a change and visionary Inspirator, which is to have a clear vision in which direction the organization, even where a country and nation will be brought.

One of the fundamental changes in the implementation of local government in Indonesia in the era of regional autonomy is the selection process of local executive leadership that is no longer selected and determined by the regional House of Representatives (DPRD), But directly by the people. The Output of this election is expected to be local executive leaders who can meet the majority preference of local communities and accelerate the formation of better governance (Adriansyah, 2015). Regional head elections are expected to undertake the 
selection process of leaders assessed by the best people to make promising changes and benefit the wider community.

Regional head elections will directly strengthen and develop the concept of checks and balances in government administration. With the regional head Elections directly, the regional head will be responsible for the people not to the DPRD. Thus the position of head of the district is sharp as a political policy executor, therefore if the position of regional head of the People's Choice is supported by an aspirational DPRD and able to perform its function correctly then the concept of check and Balances will be carried out well for the benefit of the people. Some supporting factors that can be used as a source of support in the selection of regional head candidates such as community trust, the quality of regional head candidates and the personality of the regional head candidate (Adriansyah, 2015).

Visionary leaders always appear in various aspects of community life. In the world of politics, economics, business, the general public, or the academic world always emerging figures that are valued for his dedication, his thinking is judged enlightening, has a vision far ahead, and therefore becomes a role model. What is done and the idea that a visionary leader developed, would usually be an inspiration, even at certain boundaries of ' ideology ' fought by his followers. In Indonesia, one of the characters who deserve to be called a visionary leader is Dahlan Iskan, CEO of Jawa Pos Group who has been able to bring various companies that are under his leadership progressing rapidly and managed to get out of crisis Who presses them. He pioneered the savings movement in his company's internal manner by slashed his salary and promised not to change glasses (which had broken one of his handles) until the Jawa Pos advanced again, but the amazing he used and the increase in the price of paper with intelligent action, that is, cut the width of the page to smaller, but it was later promoted as a more sexy newspaper size for its readers. The chosen step proved successful because Jawa Pos can save on production costs even though the price of paper rises, and at the same time, attract new readers with an attractive new look (Adriansyah, 2015).

A few political figures that deserve to be called as visionary leaders are Nelson Mandela, Mahathir Muhammad, Lee Kuan Yew, Sukarno, Suharto, Habibie, or others. They deserve to be categorized as visionary leaders for their ability and integrity, as well as (most importantly) because of his distant views, past the deadline, and two-three steps ahead of the people he led. Lee Kuan Yew, often referred to as the proud leader of Asia because of its ability to advance Singapore's small country into one of the international business icons. After understanding the competencies, roles, and traits of the visionary leader that was in the Find by Burt Nanus (1992), then in this case study, I was deeply inspired to illustrate how a successful district leader led one of the cities in West Sumatra. They are also worthy of being said to be the visionary leader, as they have made many changes in Sawahlunto city that have been in chaos due to the depletion of coal reserves as supporting the regional economy, but in their hands, the city Sawahlunto finally stretched back.

\section{THE VISIONARY LEADER OF SAWAHLUNTO}

Leaders of the Visionary must be able to manage the continual changes that are not always fixed and stiff in the rules that defuse, otherwise it must be flexible and good at reading the changes that occur in the vicinity in order to respond immediately to changes Quickly, immediately learn to adapt and be able to respond to changes with innovative measures (Hesselbein \& Johnston, 2005). Since Indonesia's mining wealth has continued to decline, because it is based on continuous exploitation of natural resources, where the resources are not renewable because of its unrenewable nature and the government is continually striving to Indonesia's economy continues to grow. However, the phenomenon of the city deterioration caused by the exploitation of the mining sector continuously seems to be inevitable, and this 
is experienced by the city Sawahlunto Sijunjung. The city of Sawahlunto has relied on the mining sector as the main livelihood of its inhabitants. However, since the loss of its production function as a mining city, the population began to leave the city Sawahlunto due to the reason the mining sector where they are hanging life is not reliable anymore as the main source of the community economy.

The city of Sawahlunto was the first mining industry activity in 1891 and reached a peak of shock in the year 1930. However, the impact of mining sector exploitation began in 1998 to 2001 where coal mining activities abandoned their society so that the decline of the city occurred. The city has almost become a ghost town with a poverty rate of $20 \%$ with a population growth rate of- $6 \%$, it shows logical consequences for the post-mining city that the inhabitants have moved and left the town of Sawalunto in 2002 Sawahlunto has eventually declared a crisis. The initiative to make the city change began from the worry of government and society to the condition of the city experiencing chaos due to the depletion of coal reserves that are used as the leading resource of supporting the economy. This paper discusses how the role of a visionary leader in making the city change and what strategies are being done to anticipate and examine the ever-changing strategic environment. Besides, this is subject to implement the excellence competition in maintaining the city's sustainability and whether this visionary leadership continues the next elected leader as well as what action they have done as a visionary leader.

During the leadership of Subari Sukardi as the mayor of Sawahlunto 1993-2003 period, the community provided the opportunity for Subari Sukardi to serve for two periods. In 2002, Sawahlunto was declared being in a crisis, this condition was predicted since 1998. This condition is an early history of change that a leader should do, who has a big dream. He acted as a change leader that establishes the direction for future vision and unites all stakeholders' organization by communicating his vision and dreams. Besides, he inspired all his followers to overcome the obstacles together. For the visionary leader, the deterioration condition of the city is not a threat of death, but momentum to do a great revolution for creating the historical record. Arnold Tonybee and Ibn Khaldum revealed that the dead city can be stretched back if the human element is ready to answer the obstacles (Conlin \& Jolliffe, 2010); (Evans, 1989); (Pretes, 2002); (Prideaux \& Timothy, 2011); (Steel, 2013). Some examples of cities that were successful out of the threat of city deaths due to mining sectors were discontinued is Hasima Island in Japan, Cartagena in Spain, the city of Essen in Germany, the city of Kartagena in southern Spain, and the city of Kolmanskop in Namibia Bodie city California (Hashimoto \& Telfer, 2017), (Alexander, 2010), (Trettin, Lutz, Neumann, Uwe, Zakrzewski, 2010), (Steel, 2013). Almost all organizations have a dream and a glimpse of the future, and the dream cannot be realized without vision and mission (Moeheriono, 2014).

Vision is one of the three pillars of the inseparable pyramid (integrated) in determining the direction of the organization, the two pillars are mission and purpose. The mission illustrates the organizational vision and vice versa as well as describe the organization's established objectives (Moeheriono, 2014). Vision, mission and objectives are predetermined before conducting strategic management or determining strategic objectives. The formulation of Sawahlunto City Vision conducted by Subari Sukardi has been pursued through the structure of the creation of the vision by the following steps: (1) Use the collective method by forming a working team to collect information as a primary reference, (2) Brainstorming to conduct income collection and draw conclusions by conducting several Focus Group Discussion (FGD), (3) Selecting the ideas that have been gathered, (4) Doing development draft of the statement that has been collected, (5) make improvements to the vision statement of Sawahlunto City in accordance with the objectives that can be achieved, (6) Conduct testing 
criteria through an internal analysis team that has been assigned to test the vision, and (7) establish, consolidate and formalize the vision of the city "Sawahlunto in the year of 2020 becomes a cultural mining tourism city" in the formal form, it is a regional regulation (PERDA) Number 2 year 2001. The vision was realized with the long-term development Plan (RPJPD) of Sawahlunto City in the period of 2013-2018.

According to RPJPD, four main missions of long-term regional development. Firstly, maintain and develop values of basic religious and customary values during society. Secondly, improve public service facilities. Thirdly, develop objects Mining tourism. Fourthly, develop the entire potential of the city that can foster tourism growth. The development of RPJPD is more geared towards improving the quality of human resources which includes improving the quality of education, increasing the degree of public health, development and as well as the application of Science and Technology (IPTEK). Some areas are related to the direction of development, such as religion and culture, law and government, and creative economics focused on local wisdom, which is independent and competitive. Some other areas also are related to development direction include infrastructure network, which is integrated into urban infrastructures and environmental development focusing on natural resources management and sustainable living environment.

The reflection of Subari Sukardi's actions is in line with the theories that are discovered by Werren Bennis and Burt Nanus (1989) who say that effective leadership has the hallmark of a nomad, work out the performance of the task, have a dream and translate it into reality, and strive to unite the commitments of its members, give encouragement to them and turn the organization into a new unity that has higher power to survive, grow, and succeeded (Adriansyah, 2015). In other words, effective leadership is the strength of the Organization in realizing welfare, both to its members and the community broadly. Burt Nanus in Visionary Leadership (2001), said effective leaders always have a plan, result-oriented, continually adopting a new vision that is challenging but accessible, communicating the vision to all its members (Nanus, 2001). A strong vision will lead to successful leadership because it is the key to organizational success. John M. Well (2019) revealed that someone can do something alone, but it is required to involve many people to be successful in achieving the vision. A successful organization requires a strong commitment leader, future vision, members enrichment in the form of good cooperation.

The success of Subari Sukardi in the change of the legitimacy structure that is the direction in the change of civilization development of Sawahlunto City as a marker and he is the key actor behind the change of the city vision through his idea of the city vision and became a reference to the next city development. Related with the next forming of cadres of leadership in Indonesia the provisions of the Law on the election of Governors, regents and mayors contain about some provisions and requirements of the selection of regional head, where one of the conditions to forward the run has never Served as governor, Regent, and mayor for 2 (two) times in the same position. Subari Sukardi has had the opportunity to lead the city of Sawahlunto as mayor for two periods, and the next elected mayor must continue it. One of the weak points that a leader often faces is in the process of forming fo cadres. Often, the survival of an organization turned out to be dependent on a single leader, so that when the leader began to enter retirement, the organization was not prepared with prospective successors who had the same reputation and capacity, much less than the former leader (Adriansyah, 2015). However this is different from that that happened in the city of Sawahlunto at the time, the selection of regional chief of Sawahlunto then again get a visionary and innovative leader, Amran Nur in his leadership made many achievements in realizing and implementing the change of the city that has been proclaimed earlier by Subardi Sukardi. Subari Sukardi could communicate the vision through a set of rules and abilities of 
Amran Nur as a recipient in accepting, understanding, welcoming, using, and providing feedback so that the vision can be achieved.

Subari Sukardi's leadership was subsequently succeeded by Amran Nur (2003-3013) (Asoka, Samri, Zubir, \& Zulqayyim, 2016). Amran Nur is a businessman from Jakarta who came from Talawi. Amran Nur was born in Talawi, Sawahlunto, West Sumatra, October 13, 1945, and died in Jakarta, Indonesia, 22 June 2016 at the age of 70, served as mayor of Sawahlunto 2003-2013 period, the term ended on 25 June 2013. Serving as mayor of the city of Sawahlunto began in 2003 through a representative system at the local DPRD, then reelected in the first general election of Sawahlunto from the independent line in 2008. Amran Nur has a strong academic background, a graduate of Institut Teknologi Bandung (ITB), and a person who has experience in the business world. As a leader of his skills and experience to be a capital enough to make a breakthrough, because he also has courage, and innovative, and has a robust national network.

Amran Nur managed to create a series of remarkable achievements for Sawahlunto, including advancing the community economy, primarily through the industry and tourism sectors. During this time, tourism in West Sumatra is usually identical with Padang and Bukittinggi, but under his leadership, Sawahlunto started to become one of the main tourist destinations in West Sumatera province. Besides, he managed to increase Sawahlunto's economic growth to be above six percent annually. The Central Statistical Agency (BPS) records, Sawahlunto is the city with the lowest second poverty in Indonesia after the city of Denpasar, Bali. Some of the achievements recorded during his leadership are the best hope I for the best planning of 2015, the grace of cultural heritage and the former Permuseuman 2014, Tourism Category award, Government Award weekly SINDO 2014, The Most Improved-Bronze, Travel Club Tourism Award 2014, The Most Improved Travel Club Tourism Award 2013, a city worthy of The year 2013 first category, Swasti Saba Padapa 2013, exclusive ASI Program optimization program, the flagship Program of nutrition category from Indonesia MDG Award 2013 and very high-performance achievement in the year 2014 in the implementation of local government based on LPPD year 2012.

At the time of his leadership, Amran Nur then continued to develop the city of Sawahlunto, which in early 2000 of the year began to be dubbed the "ghost town". The term "ghost town" appears as the city begins to be deserted. Coupled with the growth of the minus population as quite a lot left the city, because of no longer the source of adequate economic income (Asoka et al., 2016). The next question is what Amran Nur does, especially to realize the vision of Sawahlunto as a cultural tourism city, how it creates strategies and programs that have been compiled in realizing the vision of the city in the form of action.

The change strategy pursued by Amran Nur to transform the "ghost town" was concentrating on the development of human resources, infrastructure, and the mining heritage tourism objects. Tourism development includes three forms, they are leisure tour, cultural and historical, and research tour. The cultural and historical tourism aims to make tourist are enjoyable and recognize all the cultural and historical potential that grew since the 19th century. A research tour encompasses a piece of cultural research and socio-plurality of society. For advance tourism, the government of Amran Nur complemented various facilities and infrastructure to support tourism and encouraged the public to improve the craft of its people as souvenirs. The social potential of the multicultural community of Sawahlunto is the uniqueness of its own that also contributes to tourism as a socio-cultural model. Tourist feels comfortable because the people are accustomed to coexistence with tribes and races. Potential and empowerment of human resources (SDM) is an important factor in the success to increase the knowledge, skills, and competencies of the city of Sawahlunto by providing training, coaching, and study. The country serves as a role model as well as the cooperation of 
external parties and other countries that are assessed successfully from its tourism sectors such as Japan, Malaysia, and Singapore. The government of Indonesia also pays attention to the management of the city's human resources by providing the opportunity to improve their competence by participating in various education and training as well as technical guidance. It includes the administration, management, and the ongoing documentation of cultural reserve, which is intended for public or governmental devices. Amran Nur is also advancing agricultural sectors, plantations, farms with various innovative development movements.

The strategy in the development of Sawahlunto City by Amran Nur is divided into three development zones. The first area is the Old City zone with the function of a central office and a mining facility, mine holes, railway stations, markets and settlements from most of the community working in the mining sector, one of the buildings of the historical area that was renovated and developed is the Goedang Ransoem area which was then transformed into the Goedang Ransoem Museum which was inaugurated in 2005, then the renovated railway station which was renovated into the railway Museum The city of Sawahlunto, Amran Nur also reopened the first mine pit of Soegar Holes which is more popularly known as holes "Mbah Soero," another renovated old building is a Dutch office house that works in coal mines, these houses are also transformed into a comfortable lodging, and a number of homestays have been established by a community facilitated by the Government so that the city of Sawahlunto as a tourist destination is ready to accommodate guests in some hundreds every day (Asoka et al., 2016). The second development zone of the resort area of Kandi where previously a coal mining area, with a varied texture of the soil, this area is then reforestation to resemble the city forest, the development of garden land, Kandi Lake Tourism and Amran Nur also build sports facilities such as racetrack and Langan Race Motor (road race) and third gate zones for recreation Center, culinary tourism, souvenir shop, and others. In order to support the tourism sector of Sawahlunto City, Amran Nur's idea to choose the weaving industry as a leading sector in promoting tourism is quite remarkable with the construction of weaving houses and village weaving Songket. Songket Weaving is one of the famous handicraft industries since a long time ago from Sawahlunto, called Songket weaving Silungkang. Weaving houses and weaving villages, equipping the sales outlets of various weaving crafts such as songket and embroidery, sarong, which grew fast enough in the gate area, in line with the development of production and market that jumped rapidly (Asoka et al., 2016). These three zones are built simultaneously that are integrated so that each zone can support each other to make the city of Sawahlunto as a tourism city of mines, which is aligned with the vision listed in Perda No. 2 the year 2002.

At te time of the leadership of Amran Nur Developments and the progress of Sawahlunto in the field of cultural arts and crafts is considered quite significant. As an indicator of success can be submitted. First, for the handicraft category, the city of Sawahlunto has spurred the growth of songket weaving, which has increased to nearly 700 people with a few songket generated 118,770 strands. Its production value is 30.9 billion more. In the year 2007 , the number of craftsmen only 312 people, but the production level is still low. It only produces 22,536 strands, with a production value of around 3.1 billion. So, the value of creativity developed by the city Sawahlunto, not only increases the number of craftsmen but also increase productivity and income with an essential stepping. Revitalizing the former mining site into a tourism object aligned with sustainable development contributes positively to the improvement of the post-economy crisis as the mining resources depleted as studied by Denise Cole and Michael R. Evan in England and Virginia USA (Cole, 2004), (Evans, 1989). The change of mining city into mining tourism has an impact on the economic strength of the community and regional economies (Hospers, 2010). The leader of change could implement the concept of learning as the basis to make a change to improve productivity for the welfare of the whole community. 
Westley and Mintzberg (1989b) studied how the vision was made and what strategies were undertaken by the visionary leaders in the executed and embodied organizational objectives. In the case of the city Sawahlunto, it is indeed not done by one visionary leader, but through a leadership. Figure 2 describes how Subari Sukardi as a visionary leader can communicate the vision of the city to Amran Nur and the ability to accept, understand, and implement the action of change through the strategy of implementing the city vision. Sawahlunto becomes a tourism mining city cultured by these two leaders deserves to be referred to as the agent of change under the role of visionary leader (Nanus, 1992).

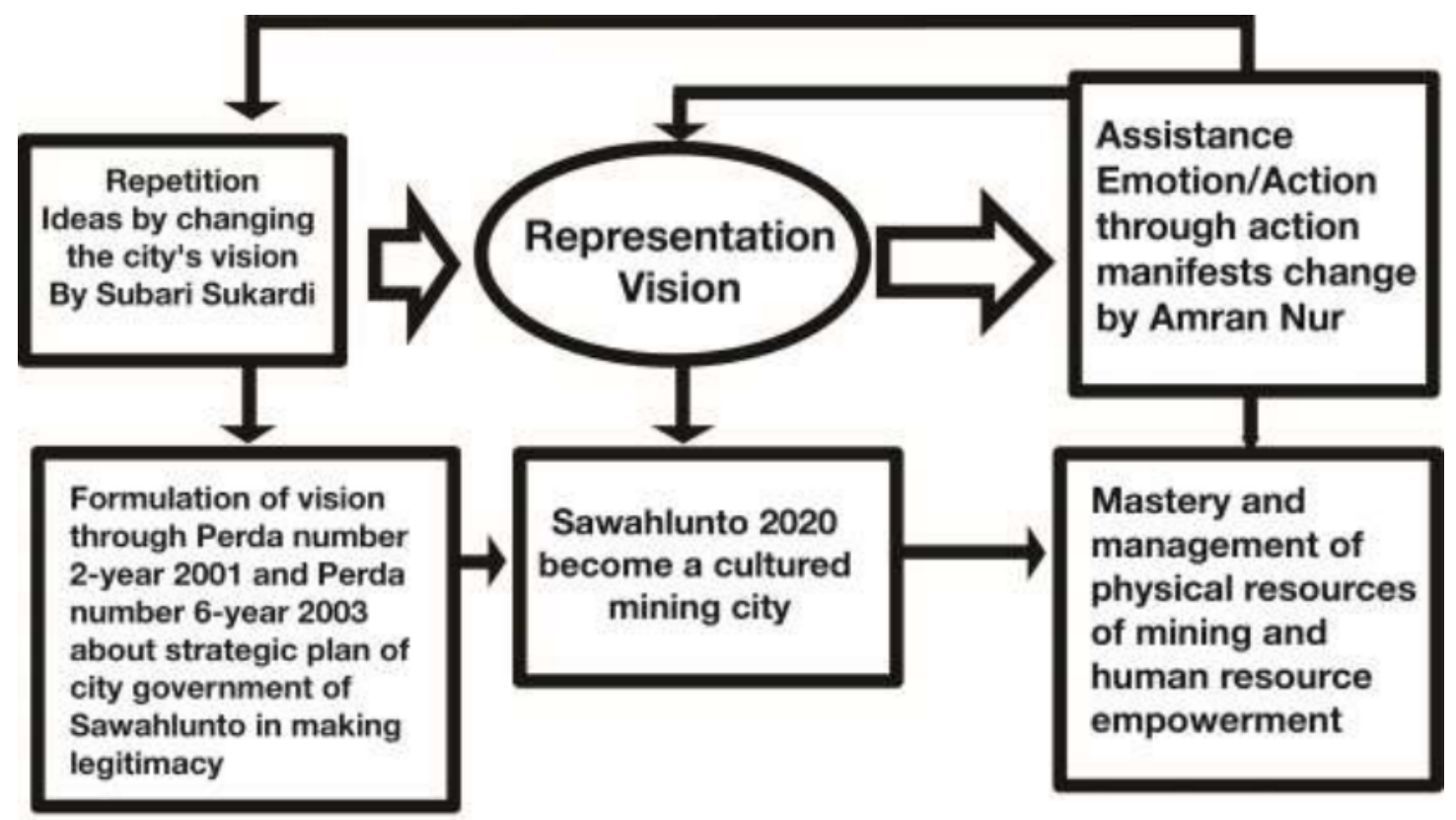

Figure 2. Visionary leader Action Scheme (Mclarney \& Rhyno, 1999)

After two periods of Amran Nur, he was succeeded by Ali Yusuf who led the town of Sawahlunto from 2013-2018. As Ali Yusuf's successor, at the time of his leadership, he developed some vision and strategies that had not yet been implemented in the previous two leadership. His action in implementing the vision of Sawahlunto is through tourism optimization and the creative economy of Sawahlunto city as well as strengthening the identity of a cultural mining tourism city. During his reign, Ali Yusuf received an award charter from the Travel Club in 2013 as the most Improver. Deri Asta continued the leadership period of 2018 to 2023. At the time of his leadership, Sawahlunto was designated as World Heritage as Ombilin Mining Heritage of Sawahlunto.

This award is not an instant endeavor, this success is a struggle that has been initiated by long-time leaders who were committed to make changes with the transformation of vision, mission, and strategy to achieve the aim of creating the city of Sawahlunto in 2020 become a cultural mining tourism city. The vision of the city that was once conceived and conveyed clearly, creatively and continuously by Subari Sukardi and succeeding leaders. A question is now addressed to new leaders on how to create a new vision and visionary leader. The leadership of Deri Asta is the assessment for the community whether he is a visionary leader who has a big dream with his revolutionary ideas. He is expected to enhance the competitiveness of Sawahlunto or simply inheriting the sustainability that has inherited by previous leaders. The visionary leadership analysis in Sawahlunto city, under the role of the visionary leader by Burt Nanus (1992), and the transformation scheme of vision on every leadership can be seen in the Figure 3 below. 


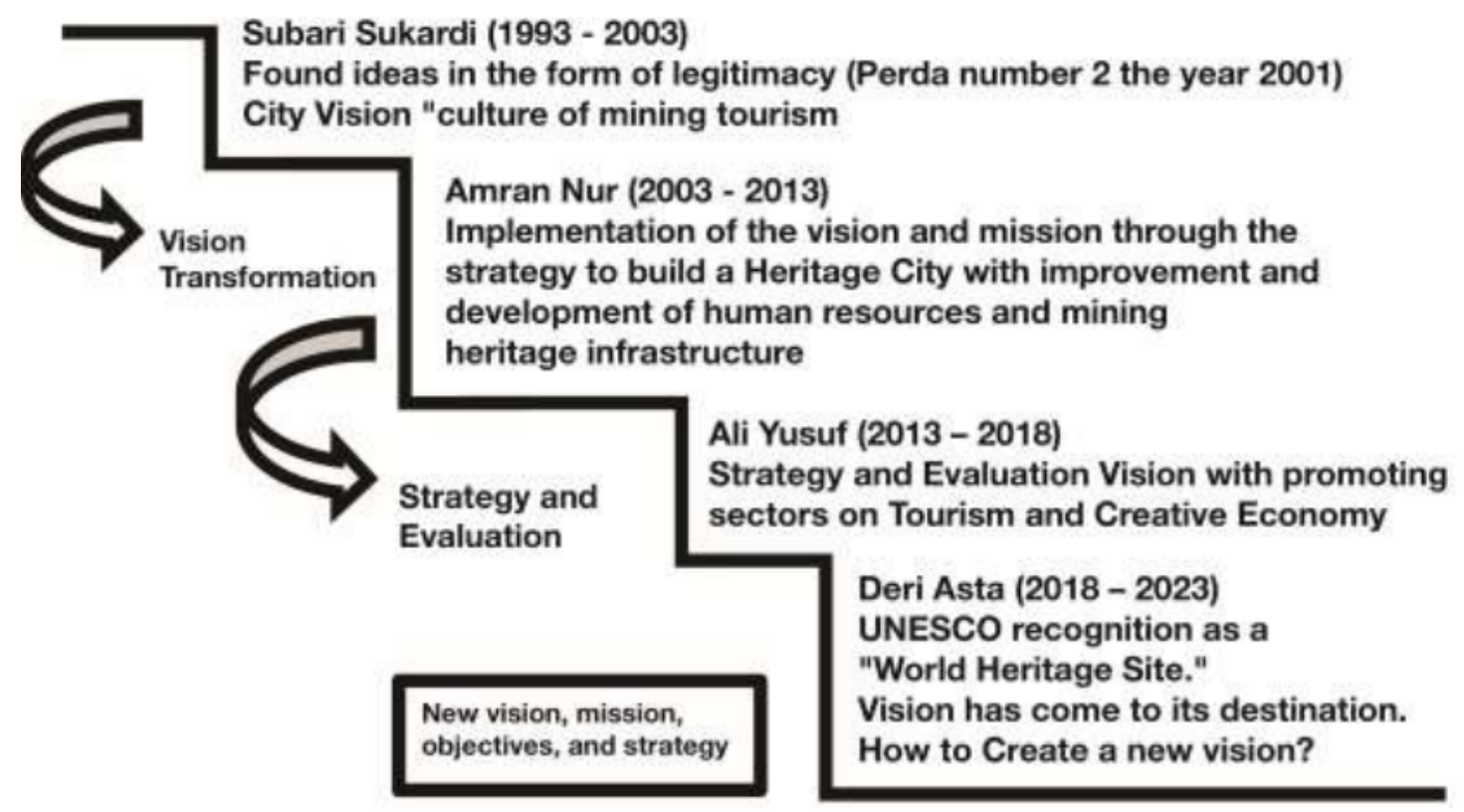

Figure 3. The role of every leadership in building city civilization

Rebuilding the city requires the visionary leader who is capable of translating the dream of the organization far ahead with innovative and revolutionary action. Vision is long-term planning because it is an essential idea and concept of innovation in preparing a vision of a minimum of 10 or 15 years ahead. The success of communicating the vision to all stakeholders makes the expected achievements achieved. Vision can indeed be born of one person, but that vision can only be accomplished through many people (Maxwell, 2019a). Vision alone is certainly not enough to have action to implement in the form of real action. Achieving the vision requires maintenance on evaluation, development, sustainability. In a certain period, the vision requires refreshment. Most sources of failure rebuild the unencountered organization of leaders who have a revolutionary vision and sustainability action performed by previous visionary leaders. Figure 4 Below is a scheme that authors offer to maintain the sustainability of a strategic vision as the role of a visionary leader.

The role of the mayor as the city leader of Sawahlunto has a different role in the process of implementing the change. Assessment of most leaders is fundamentally successful and influential in implementing the change of Sawahlunto Known as the visionary figure is Amran Nur. The indicators are his strategies and actions to bring the city of Sawahlunto out of crisis and significant changes to the mining's relic infrastructure. However, what needs to be realized is that the change can happen through the first vision of Subari Sukardi. The visionary leader is sometimes just going to be a hidden actor, his achievements will appear after a while, and it may not be during his reign. In an interview with the city community of Sawahlunto, they assess Amran Nur as a leader who successfully led under challenging times. They argue Amran Nur is the visionary and change leader who do various innovation not only for him but for the welfare of society. He is also known to the community as the father of Sawahlunto. The change leader must be visionary because he should be able to see far ahead of where the organization must move and change the organization planned to be part of the task of a leader (Dimiyati, 2014). 


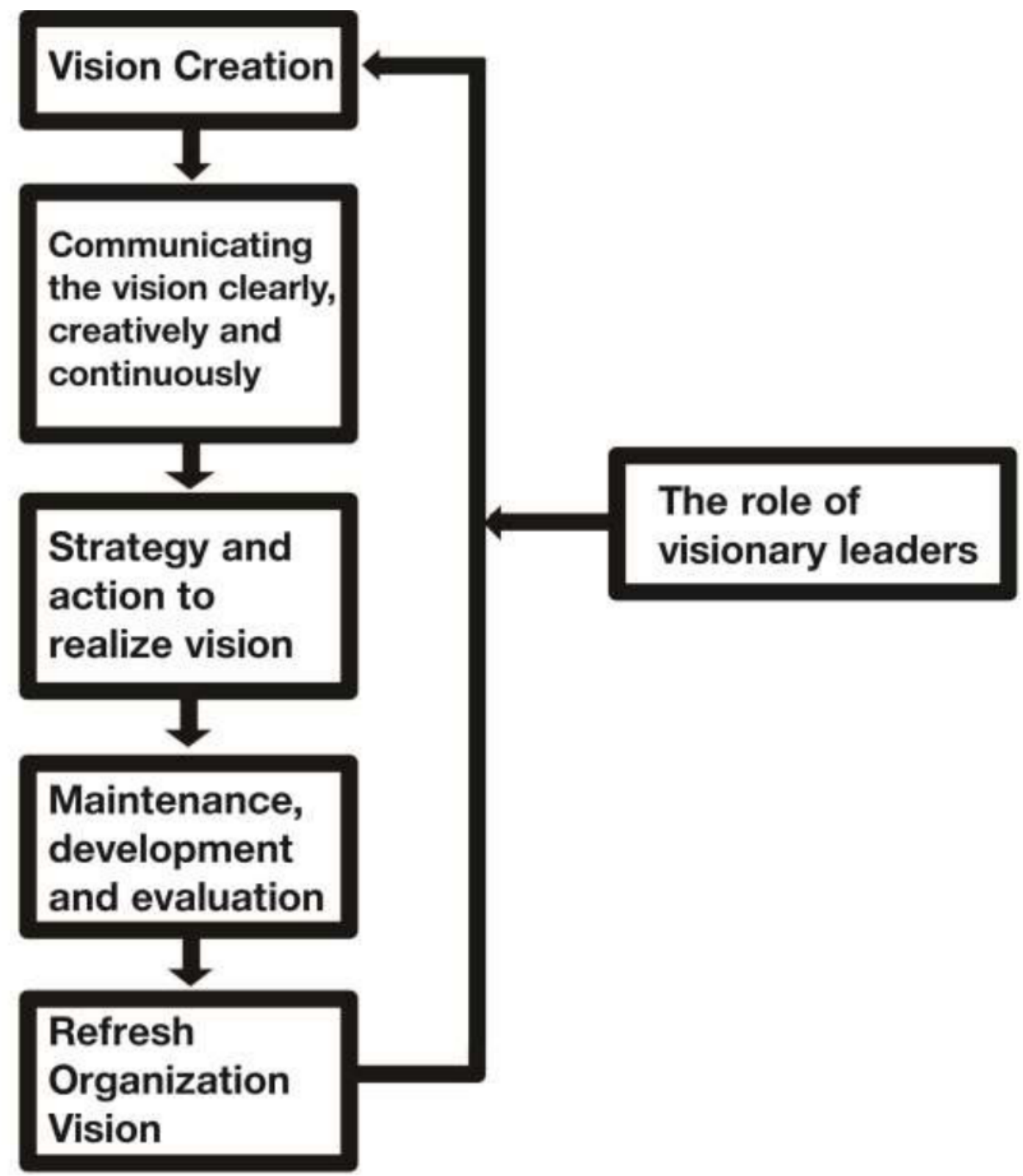

Figure 4: Sustainability Scheme of vision transformation

\section{VISIONARY UNIVERSITY SUCCESS AND FREQUENTLY ENCOUNTERED OBSTACLES}

McClelland also finds that in terms of effective behavioral managers are the opposite of the dominant manager of stereotypes who make all decisions alone and keep strict authorities. Conversely, effective managers involve their subordinates, allowing subordinates to participate in decisions, and delegating authority (Sashkin, 1987). The results of the study Keith Davis (1972) concluded, there are four traits or traits of leaders that can lead to success in the lead, the first intelligence which means, the leaders, in general, are relatively smarter than the average of his followers, both Have a motivation and an accomplished desire from within, meaning that the leader generally has a great urge to be able to accomplish something, three maturity and the breadth of social views, meaning that the leader in the emotion generally always Mature, so as to be able to control the critical state, generally they also have 
confidence and confidence in oneself, fourth, have the ability to hold relationships between people, meaning that the leader knows that to accomplish something They are very dependent on others, therefore they always want to be able to understand others, they are oriented to subordinates, the successful leader is always a creative thinker. They know how to look from the outside in, challenge the status quo, move proactive, see and develop talent and translate the vision of the future (Adriansyah, 2015).

The success of vision transformed into a cultured mine tourism city is not detached from the role of the visionary leaders who have a distant view in formulating the vision and to write it in the form of legitimacy that can Become a reference for subsequent leadership. Restrictions on regional lead rules tend to often be constraints if subsequent leaders do not have the same vision. Subari Sukardi has been successful in convincing all Sawahlunto stakeholders with success in transforming the city's vision into a cultured mine tourism city, but in realizing the vision in the form of action, he was constrained by his tenure is exhausted. In some cases, the forming of cadres of leadership becomes a severe problem for the progress of the area when the next elected leader has a different vision. Amran Nur is the second visionary leader to capture the ideas and concepts of the vision and make it happen with an innovative event by conducting some of the most revolutionary measures of perfectly that have been assessed in the city's vision. One of the actions undertaken by Amran Nur in executing the former mining area, the Goedang Ransoem museum that has been occupied by the community for many years since mining activities were discontinued, recollecting objects Mining history, he attempted to use a ' win-win ' approach rather than ' win-lose ' by making a replacement, such as a resident who had lived in the museum as a residence he replaced it with a search for change Housing for the residents and replacing any historical goods returned to the government. In this case, Amran Nur has done an approach that corresponds to the philosophy of the Minangkabau people "Lamak manned, Katuju diurang" with the meaning that to realize his dream does not harm others, he builds what his name "Bring us to do together."

From the analysis of the successful authors obtained by the Sawahlunto city is not separated from the leaders who are creative, visionary, and innovative to make revolutionary changes as holders of authority legal rationale. Each person gives a new vision, of course, will be followed by a change and the tendency of change often gets rejected because not everyone likes to change. However, the change in the vision of Sawahlunto is the aspiration and opinion of the various parties and communities of Sawahlunto that further become a shared vision to implement participatory development as a solution out of the problem of city death post-mining closed.

The credibility of a leader is undoubtedly not only determined by their ability to develop innovative ideas and formulate tactical and strategic organizational development measures, but precisely what is essential is the ability The leader faced crises, heavy pressures being experienced, and some leaders proved to be successful in bringing out organizations led from various issues that were in the midst of it. More than a creator who can see a chance that nobody else sees and then takes advantage of it, the leader needed in this 4.0 revolution era is increasingly competitive like a leader who remains robust despite the organization he led Facing problems, and at the same time able to overcome and change the various limitations faced to be the main opportunities and advantages of the organization or company. When faced with difficulties, a formidable leader will see it as a temporary nature, as they are generally a person who never gives up and has good optimism. Having a forward, ambitious, cold-handed vision, and a willingness to learn from weaknesses and mistakes in the past are the combined characteristics that a leader should have in addressing the crisis and progress challenges (Adriansyah, 2015). Subari Sukardi was successful with the city's vision and the 
success of Amran Nur as a leader who dared to make changes and to take significant action. He made a groundbreaking breakthrough that was not thought by others. The challenge of being an opportunity, the use of all the potential resources of change, the utilization of various resources from various mining relics into important capital support the change of rebuilding the city civilization. Public disclosure received change is also a factor supporting the success of Sawahlunto. The collaboration of local governments and communities in the management of human resources as a drive for city change can also be seen from the growing potential of women entrepreneurs in the MSMES sector. The growing star-up entrepreneurs in the creative economy sector and the growth lifecycle of the weaving industry are successful in changing the paradigm of weaving crafts. It was only learned by women of the elderly, but today, it has been studied by young children and served as a skill which is inherited not only by women but also by men.

The time needed to be able to see the change of Sawahlunto city from the city of mines to be a cultural mine tourism city happen in a long time. What is reflected in the new regional long-term development plan (RPJPD) is done and reap the results in the period of approximately 15 years. The visionary leader deeply understands his role as a leader, he further precedence the need and the interests of the organization (Maxwell, 2019a). The vision to be Sawahlunto in 2020 culture mining tourism city has reached its destination in 2020, this year is a momentum in the reproducing of a new vision for the future of Sawahlunto. The current visionary leadership competency of the mayor has very popular credibility as the leader of Sawahlunto. The sustainability aspect of the organization and preparing the process of cadres forming or prospective substitute leaders considers that there is no leadership degradation occurs so that the vision needed to be brought down, and new vision needs to be executed by the next leadership.

\section{CONCLUSION}

Environmental change that happens so fast, it takes leadership that has a lot of innovation, creativity, forward vision, values, assumptions and a promising paradigm, which can empower all potential resources of successful organizational success. Without the vision and values that support the organizational structure to the future, leaders may not be able to make decisions in line with the objectives of the Organization, in carrying out management functions in the organization that is planning, budgeting, organizing, actuating, coordinating, controlling as well as evaluating.

Visionary leadership is the absolute requirement for organizations that want to grow decades ahead, so the vision becomes very important, the vision of being all for a leader, because of the viol leading the leader, Vision will color the target and become fuel move the progress. Vision also serves as a trigger of passion for others to follow the leader, if a leader who is without a vision will not accomplish anything he is merely spinning a spin in a circle, visionary leadership is believed to be able to adapt Organization that led to the ever-changing external environment.

Subari Sukardi is a visionary leader who has been interested in the idea of changing the city's vision as the main foundation of Sawahlunto city. He initiated the idea in 2001 by making the vision as local government Regulation No. 2 the year 2001 and pouring vision, mission, objectives and direction of city development policy in the RPJPD. Amran Nur is a character who acted as the main character in various strategic places by making major changes to the city of Sawalunto becoming a cultured mining tourism city. One of the actions undertaken by Amran Nur in executing the former mining area, the Goedang Ransoem museum that has been occupied by the community for many years since mining activities were discontinued, recollecting objects Mining history, having used the ' win-win ' approach 
rather than ' win-lose ', he built what he called "bring us to do together " in Minangkabau philosophy "bakito kito, ba awak awak" without prejudice to the interests of society, With the phrase "lamak diawak katuju diurang".

The achievement of the city of Sawahlunto boasts not only for the city of Sawahlunto, but West Sumatra and Indonesia when the town of Sawahlunto is crowned as a World Heritage site in 2019 by UNESCO. Transforming the vision of the mining city into a cultural mining tourism city is proving that the changes made by the visionary leader and all stakeholders of Sawahlunto can change the city's civilization to revive the city's death into a cultured mining tourism city. Human role as driving change should always paying attention, giving education, and training the HR to improve skills, knowledge, competence, and experience comprises an investment towards competent and skilled human resources. The success of the visionary leader in human resources development has impacted the potential of entrepreneurs in the creative economy sector.

The vision formulation becomes Sawahlunto 2020 to be a tourist city mining culture short and easy to remember, give the motivation to get out of the crisis to an ideal state for organizations and stakeholders, clear direction and focus strategy, and have orientation on the future of Sawahlunto. This vision fosters the intention and commitment of all members of the organization to make it happen. The visionary leader was unable to establish his vision; he needed the support of all the followers and stakeholders that support the change. The current change of city civilization is the joint result between the leader and the active participation of the community. The visionary leader tends to be a hidden actor in any change when the measure of success is only on something that seems to be a change in infrastructure, but it is the most critical vision as a guide to sustainable development.

With the provisions of the Government, it serves as a district official only twice the period in the name and title; another issue is that focuses on account for the cadres forming of the next visionary leadership so that what is inside into the form of the vision by the previous leader can be continued by subsequent leadership. It is subject to implement the sustainability of the development that is in line with the organizational vision.

The community must be smarter in using the right to elect the next common area so that the elected leader is a leader who can offer a new vision for the sustainability of the city's progress, as has been done by Subari Sukardi and Amran Nur. Momentum in 2020 is an indicator that the vision proclaimed by Subari Sukardi has come to its destination, with parables such as the saying of the Minangkabau people "customary use new, worn-out cloth" if the rules are worn and obeyed, the rules will be increasingly cared for and otherwise, he will come to his age to be done renewal again.

\section{FUTURE RESEARCH}

Being a visionary leader is not only needed by organizations such as the local government in building city civilization, but further research will also be increasingly interesting to explore visionary leadership in colleges. In general, some of the colleges have had a vision that has long been formulated, how about the presence of a director or rector when he was elected as a leader, how he can align his vision with the vision Colleges that had been older than his reign.

\section{REFERENCES}

[1] Adriansyah, Kepemimpinan Visioner Kepala Daerah. Jakarta: Fakultas Ilmu Sosial dan Ilmu Politik Universitas Prof. Dr. Moestopo Beragama, 2015

[2] Alexander, N, Kolmanskop: An Industrial Heritage Resource or Only a Tourist Attraction. University of Cape Town, 2010 
Makna Ani Marlia, Rahmi Fahmy, Hendra Lukito, Ratni Prima Lita, Rida Rahim

[3] Almog-Bareket, $G$ Visionary Leadership in Business Schools: An Institutional Framework. Journal of Management Development, 2012, https://doi.org/10.1108/02621711211219086

[4] As-Sadeq, H. A., \& Khoury, G. C, Leadership Styles in the Palestinian Large-Scale Industrial Enterprises. Journal of Management Development, 2006, https://doi.org/10.1108/02621710610692043

[5] Asoka, A., Samri, W., Zubir, Z., \& Zulqayyim, Sawahlunto, Dulu, Kini dan Esok Menjadi Kota Tambang yang Berbudaya. Sawahlunto: Lembaga Pengembangan Teknologi Informasi dan Komunikasi (LPTIK) Universitas Andalas, 2016

[6] Bass, B. M, Leadership and Performance beyond Expectations. New York, NY: The Free Press, 1985

[7] Bass, B. M, Bass \& Stogdill's Handbook of Leadership: Theory, Research, and Managerial Applications (3rd ed). New York, NY: The Free Press, 1990

[8] Bryman, A, Leadership and Organizations. London: Routledge \& Kegan Paul, 1986

[9] Bryman, A, Leadership in organizations. London: Sage Publications, 1996

[10] Cole, D, Exploring the Sustainability of Mining Heritage Tourism. Journal of Sustainable Tourism, 12(6), 2004, 480-494. https://doi.org/10.1080/09669580408667250

[11] Conger, J. A, Charismatic and Transformational Leadership in Organizations: An Insider's Perspective on these Developing Streams of Research. Leadership Quarterly, 1999, https://doi.org/10.1016/S1048-9843(99)00012-0

[12] Conlin, M. V, \& Jolliffe, L, Mining Heritage and Tourism: A Global Synthesia. USA and Canada: Roudledge, 2010

[13] Delyser, D, Authenticity on the Ground: Engaging the Past in a California Ghost Town. Annals of the Association of American Geographers, 89(4), 1999, pp 602-632. https://doi.org/10.1111/0004-5608.00164

[14] Dimiyati, H, Model Kepemimpinan \& Sistem Pengambilan Keputusan (I; B. A. Saebani, Ed.). Bandung: CV Pustaka Setia, 2014

[15] Evans, K, Tourism in a Rural Area-a Coal Mining-County Experience. Tourism Manajement, 1989, pp 315-321.

[16] Fahmi, I, Pengantar Ilmu Kepemimpinan (1st ed.). Jakarta: PT. Raja Grafindo Persada Jakarta, 2018

[17] Goleman, D, Leadership: The Power of Emotional Intelligence. In Journal of Chemical Information and Modeling, 2011, https://doi.org/10.1017/CBO9781107415324.004

[18] Greenberg, J, Organizational Behavior: The State of the Science (2nd ed). Mahwah, NJ: Lawrence Erlbaum Associates, 2003

[19] Greenberg, J., \& Baron, R, Behavior in Organizations (7th ed). Upper Saddle River, NJ.: Prentice-Hall, 2000

[20] Groves, K. S, Leader Emotional Expressivity, Visionary Leadership, and Organizational Change. Leadership and Organization Development Journal, 2006, https://doi.org/10.1108/01437730610692425

[21] Hashimoto, A., \& Telfer, D. J, Transformation of Gunkanjima (Battleship Island): from a Coalmine Island to a Modern Industrial Heritage Tourism Site in Japan. Journal of Heritage Tourism, 12(2), 2017, pp 107-124.

[22] Hesselbein, F., \& Johnston, R, A Leader to Leader Guide, On Creativity, Innovation, and Renewal Insights from The Drucker Foundation's Award-Winning Journal. Jakarta: Elex Media Komputindo, Kelompok Gramedia Jakarta, 2005 
[23] Hollander, E, Leadership Dynamics: A Practical Guide to Effective Relationships. In The Academy of Management Review, 1979

[24] Hospers, G, Industrial Heritage Tourism and Regional Restructuring in the European Union. 10(3), 2010, pp 37-41. https://doi.org/10.1080/09654310220121112

[25] Kast, F., \& Rosenzweig, J, Contingency Views of Organization and Management. Chicago, IL: Science Research Associates, 1973

[26] Kotter, J, A Force for Change: How Leadership Differs from Management. New York, NY: The Free Press, 1990

[27] Lauer, H. R, Perspektif Tentang Perubahan Sosial. Jakarta: Bian Aksara, 1993

[28] Luthans, F, Organization Behavior. Yogyakarta: ANDI Yogyakarta, 2006

[29] Luthans, F, Organizational Behavior. Yogyakarta: ANDI Yogyakarta, 2006

[30] Manning, T., \& Robertson, B, The Dynamic Leader - Leadership Development Beyond the Visionary Leader. Industrial and Commercial Training, 2002, https://doi.org/10.1108/00197850210429110

[31] Martono, N, Sosiologi Perubahan Sosial. Jakarta: Rajawali Pers, 2011

[32] Maxwell, J. C, The Maxwell Daily Reader (12th ed.). USA: Thomas Nelson Inc, 2019

[33] Mclarney, C., \& Rhyno, S, Mary Parker Follett: Visionary Leadership and Strategic Management. Women in Management Review, 1999,

[34] Nanus, B, Visionary Leadership: How to Re-Vision the Future. The Futurist 1992

[35] Nanus, B, Visionary Leadership. San Francisco: Jossey-Bass Inc., Publishers, 1992

[36] Nanus, B, Kepemimpinan Visioner; Menciptakan Kesadaran akan arah dan Tujuan di Dalam Organisasi. Jakarta: Prenhallindo, 2001

[37] Ndalamba, K. K., Caldwell, C., \& Anderson, V, Leadership Vision as a Moral Duty. Journal of Management Development, 2018, https://doi.org/10.1108/JMD-08-2017-0262

[38] Nwankwo, S., \& Richardson, B, Quality Management Through Visionary Leadership. Managing Service Quality: An International Journal, 1996,

[39] O’Connor, J. J., \& Jennings, E. E., An Anatomy of Leadership: Princes, Heroes, and Supermen. The American Catholic Sociological Review, 1960,

[40] Pierce, J., \& Newstrom, Leaders and the Leadership Process: Readings, Self-Assessments \& Applications. New York, NY.: McGraw-Hill, 1995

[41] Pretes, M, Touring Mines and Mining Tourists. Annals of Tourism Research, 29(2), 2002, pp 439-456. https://doi.org/10.1016/S0160-7383(01)00041-X

[42] Prideaux, B., \& Timothy, D. J. (2011). From Mining Boom Towns to Tourist Haunts: The Gost Town Life Cycle. In M. V Conlin \& L. Jolliffe (Eds.), Mining Heritage and Tourism Newyork: Routledge, 2011, pp. 227-238.

[43] Rafferty, A. E., \& Griffin, M. A, Dimensions of Transformational Leadership: Conceptual and Empirical Extensions. Leadership Quarterly, 2004, https://doi.org/10.1016/j.leaqua.2004.02.009

[44] Robbins, S. P, Organizational Behavior: Concepts, Controversies and Applications. In Development, 1996

[45] Robbins, S. P, Organizational Behavior (Internatio). Upper Saddle River, N: PrenticeHall, 2003

[46] Sashkin, M, A New Vision of Leadership. Journal of Management Development, 1987, https://doi.org/10.1108/eb051650 
[47] Simpson, K. F., \& Fiedler, F. E, A Theory of Leadership Effectiveness. Industrial and Labor Relations Review, 1969, https://doi.org/10.2307/2520997

[48] Stam, D. A., van Knippenberg, D., \& Wisse, B, The Role Of Regulatory Fit in Visionary Leadership. Journal of Organizational Behavior, 2010, https://doi.org/10.1002/job.624

[49] Steel, G, Mining and Tourism. Latin American Perspectives, 40(2), 2013, pp 237-249. https://doi.org/10.1177/0094582X12468866

[50] Stogdill, R, Handbook of Leadership. New York, NY.: The Free Press, 1974

[51] Stogdill, R. M, Personal Factors Associated With Leadership; A Survey of the Literature. The Journal of Psychology, 1948, https://doi.org/10.1080/00223980.1948.9917362

[52] Suprayitno, Pemimpin Visioner Dalam Perubahan Organisasional. Jurnal Ekonomi Dan Kewirausahaan, 2007

[53] Taylor, C. M., Cornelius, C. J., \& Colvin, K, Visionary Leadership and its Relationship to Organizational Effectiveness. Leadership and Organization Development Journal, 2014, https://doi.org/10.1108/LODJ-10-2012-0130

[54] Tomsic, M., \& Sinclair, A, A feminist case for leadership. In Diversity in Leadership: Australian women, past and present, 2014, https://doi.org/10.22459/d1.11.2014.01

[55] Trettin, Lutz, Neumann, Uwe, Zakrzewski, G, Essen and Ruhr Area - The European Capital of Culutal 2010: Development of Tourism and the Role of SMEs. 50th Congress of the European Regional Science Association; Sustainable Regional Growth and Development in the Creative Knowledge Economy. Jonkoping, Sweden, 2010

[56] Visionary leadership: Creating a Compelling Sense of Direction for your Organization, The Journal of Academic Librarianship, 1993, https://doi.org/10.1016/00991333(93)90713-f

[57] Westley, F., \& Mintzberg, H, Visionary leadership and Strategic Management. Strategic Management Journal, 1989, https://doi.org/10.1002/smj.4250100704

[58] Westley, F., \& Mintzberg, H, Visionary Leadership and Strategic Management. Strategic Management Journal, 10(1 S), 1989, pp 17-32. https://doi.org/10.1002/smj.4250100704

[59] Yoeli, R., \& Berkovich, I, From Personal Ethos to Organizational Vision: Narratives of Visionary Educational Leaders. Journal of Educational Administration, 2010, https://doi.org/10.1108/09578231011054716

[60] Zainal, V. R., Hadad, M. D., \& Ramly, M. R, Kepemimpinan dan Perilaku Organisasi (12th ed.). Jakarta: PT. Raja Grafindo Persada Jakarta, 2017

[61] Zhou, L., Zhao, S., Tian, F., Zhang, X., \& Chen, S, Visionary Leadership and Employee Creativity in China. International Journal of Manpower, 2018, https://doi.org/10.1108/IJM-04-2016-0092 